\title{
YONAR, Gönül (2019). Kıyamet Mitolojileri (Kurtla Kyyamete Kalmak). İstanbul: Ötüken Neşriyat. 270 s.
}

\author{
Şeyda ALTAY* \\ "Gerçek anlamda yeni bir şeyin başlayabilmesi için \\ eski çevrimin kalıntı ve yıkıntıları tümüyle yok olmalıdır. \\ Bir başka deyişle, mutlak bir başlangıç elde etmek istenirse \\ dünyanın sonunun kesin olmasi gerekir." \\ Mircea Eliade
}

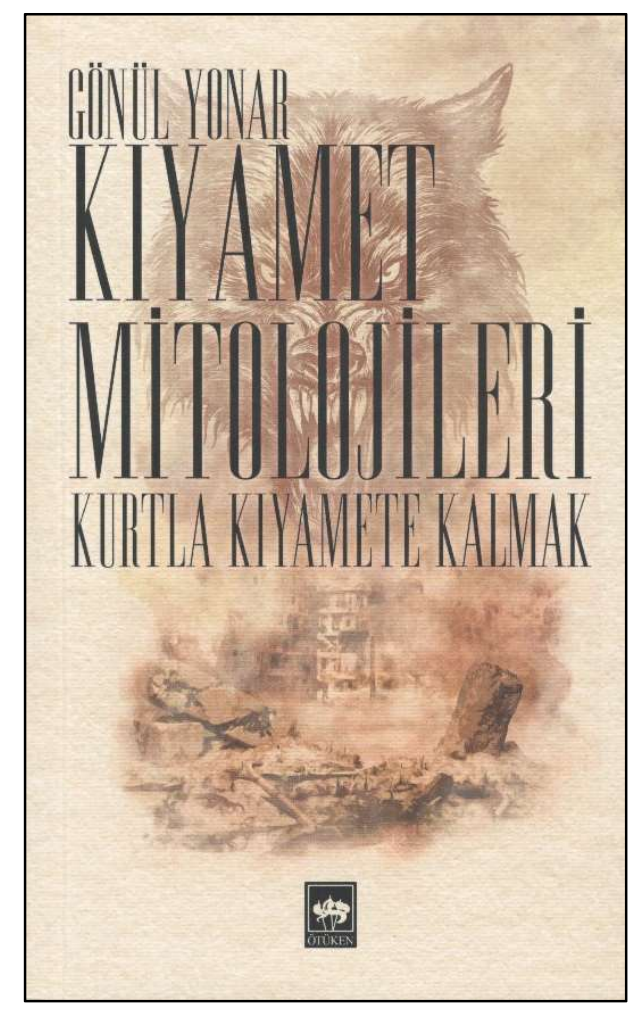

Gönül Yonar tarafından kaleme alınan Klyamet Mitolojileri (Kurtla Klyamete Kalmak) adlı kitap, Ekim 2019'da Ötüken Neşriyat aracılığıyla okurlarla buluştu. Toplam 270 sayfadan oluşan çalışma, $12 \times 19,5 \mathrm{~cm}$ boyutlarında olup kitabın ön kapağında yazarın ve kitabın ismi bir dizin hâlinde verilmiştir. Kitabın ön yüzünde yer alan ve Türkler için önemli bir motif olan "kurt" figürü ve kıyameti andıran bir "yıkıntı" resmi de kapakta dikkati çekmektedir. Bu resimlerin kitabın ismi ve içeriğiyle uyumlu olması, eserdeki bütünlüğü sağlamıştır. Kitabın arka kapağında ise, yazarın ilk eseri olan Yaratılış Mitolojileri (2018) kitabı ve devamını getirdiği ikinci eseri olan Klyamet Mitolojileri (Kurtla Klyamete Kalmak) kitabı hakkında okuyucuları aydınlatan ve kitap hakkında fikir yürütmelerini sağlayan bilgilerin verildiği görülmektedir.

Kitabın jenerik sayfasından hemen sonra yazarın hayatı hakkında (s.5) kısa bir bilgi verilmiştir. Akabinde gelen sayfada "Kızım Ayşe Beyza'ya" şeklinde bir ithaf cümlesi bulunmaktadır. Eserin "İçindekiler" kısmı (s.7-10) beş ana başlıktan oluşmakta ve her başlığın altında küçük alt başlıklar yer almaktadır. "Içindekiler" bölümünden sonra gelen "Giriş" (s.11) başlığının altında ise yazar, "Kitaba Dair" (s.13-17) şeklinde bir alt başlık kullanarak 2018 yılında İstanbul/Çengelköy'de yazmış olduğu ve okuyucuyu kitap hakkında aydınlatan satırlara yer vermiştir.

\footnotetext{
* Yüksek Lisans Öğrencisi, Karamanoğlu Mehmetbey Üniversitesi, Sosyal Bilimler Enstitüsü, Türk Dili ve Edebiyatı Ana Bilim Dalı.

e-posta: seydaaltay705@gmail.com
} 
Kitabın içeriğine dair değerlendirmelere geçmeden önce, "Kitaba Dair” başlığının altındaki satırları kısaca özetlemek faydalı olacaktır. Yonar bu kısımda ilk kitabı olan Yaratılış Mitolojileri kitabından da bahsederek evrenin yaratılışındaki mitsel anlatıların evrenin yok oluşunda da etkili olduğu üzerinde durmuştur. Yaratılış Mitolojisi'nin ardından "Bir başlangıç varsa bir de son vardır." diyen yazar, Klyamet Mitolojileri (Kurtla Klyamete Kalmak) adlı bir kitap yazmayı ve başladığı serüveni sürdürmeyi doğru bulduğunu ifade etmiştir. Yonar bu kitabında Türk, İran, İbrani ve Hristiyan eskatolojileri hakkında bilgi vereceğini söyledikten sonra, eskatoloji içerikli kaynaklarda yer alan üç konuyu kapsam dişında tuttuğunu belirtmiştir. Biri bireysel eskatoloji yani insanın ölümü, diğeri bireysel ölümün artalanları olan "öte dünya" tasavvuru, üçüncüsü ise tufan hadisesidir (s.14). Yonar'ın tufan ile kıyameti eşdeğer görmemesinin sebebi, bu eylemlerin sonunda ortaya çıkan durumdur. Tufan, kâinatın tamamen yok oluşu değildir ve tufanın ardından iyilerin kurtulup yeni bir düzen kurdukları görülmektedir. Oysa kıyamet, sonsuz yok oluş demektir ve devamında yeni bir dünya düzeni oluşmamaktadır. Bu sebeple yazarın tufan konusuna değil, kesin son olan kıyamete odaklandığını görmekteyiz. Yonar, devamında "Bu çalışmada ilk kez üç büyük semavi din olan Hristiyanlık, İslamiyet ve Yahudilik dinlerinin eskatolojik olayları ve sonları hakkında bilgi verilmektedir. İlk kez bu üç büyük dinin, dünyanın sonuna dair kutsal anlatıları bir araya getirilmiş, benzerlikler ve farklılıklar ortaya konulmuştur." (s.16) diyerek eserinin en önemli yerine de vurgu yapmıştır.

Kitap, 5 bölümden oluşmakta ve her bölüm, farklı bir kavmin eskatolojik sonunu anlatmaktadır. Bahsi geçen beş bölümden sonra ise "Kaynakça" (s.260-270) bölümü gelmektedir.

Kitabın Birinci Bölümünde (s.49-65) Pers İmparatorluğu'nun dini olan, içerisinde düalist ve eskatolojik inanışın ilk örneklerini barındıran, dünyanın en eski tek tanrıcı vahiy dini Zerdüştlük hakkında bilgiler verilmektedir. Zerdüşt inanışında dünya, uzaktan kendisine atılan bir ateş topu ile alev alacaktır. Bu alevin etkisiyle bütün metaller ve dağlar eriyerek bir nehir oluşturacaktır. Akan bu nehirden sadece iyilik yapan insanlar geçebilecek; kötülerse nehrin akıntısında kaybolacaktır. Bu nehir, Türklerin inanışındaki sırat köprüsünü anımsatmaktadır. Tanrı son bir şans olarak Saoşyant'ı insanlara yardım etmesi için gönderecektir. Saoşyant insanlığı kurtarmak için kutsal boğayı kurban edecek ve yağından ölümsüzlük içeceğini hazırlayacaktır. Bu yağdan içen herkes artık ölümsüz sayılacak ve sonunda yine iyilik kazanacaktır.

Kitabın İkinci Bölümünde (s.67-120) İbrani eskatolojisine, yani Yahudilerin eskatolojisine değinilmektedir. Yahudi külliyatında Yeşaya'da ve benzer kitaplarda yer alan ahiret ile ilgili ayetler yer almaktadır. Kitapta ise ayetlerden şu şekilde alıntı yapılmaktadır: "Dünya alt üst olacak, göklerin kapıları açılacak, dünyanın temelleri sarsılacak, yeryüzü büsbütün çatlayıp yarılacak, her yer sarsıldıkça sarsılacak, dünya sarhoş gibi yalpalayacak, insanlar isyanlarının ağırlığı altında çökecek ve bir daha yerlerinden kalkamayacaktır. O gün ne kaçacak ne de gidilebilecek bir yer olacak, herkes bu büyük sonla karşılaşacaktır." 
Ayrıca Yahudi eskatolojisine göre, dünyanın sonunu insanların azgınlaşmaları ve haddi aşarak Rabb'e isyan etmeleri getirecektir. (s.81) Yine aynı inanışa göre, kötülerin cezalandırılmasının ardından Mesih gelecektir. Mesih, beklenen kurtarıcıdır. Mesih'in gelmesiyle yeryüzü yeniden doğacak ve iyilik kıvılcımları yeniden görülmeye başlayacaktır.

Kitabın Üçüncü Bölümünde (s.121-160) detaya girmeden Türklerin eskatolojisine değinilmiştir. Eski Türk yazıtlarında, eskatolojik düşünce hususunda dünyanın sonu için göğün çökeceği ve milletin mahvolacağ 1 şeklinde bir yorum yapılmaktadır. Türkler öldüklerinde Tanrı'nın katına çıkacaklarına inanmaktadır. Çünkü onların inancında ölen bedendir, ruhsa yaşamaya devam edecektir. Anadolu sözlü geleneği içinde anlatılan mitsel hikâyelerin eskatolojik sonunda, bütün insanlık yok olacak, sadece bir kurt ayakta kalmayı başaracaktır. Bu açıdan bakıldığında "kurt", Türk yaratılış mitolojisinde bir türeyiş nesnesidir. (s.149) Yaratılış efsanelerine göre, Ülgen iyilik için gelen tanrıdır. Erlik ise kötülük tanrısı olup kıskançlık, bencillik gibi kötü duygularından ötürü tamuya (cehenneme) gönderilmiştir. Bu sebeple cehennem kötülerin ve kötülüklerin yeridir. Hâliyle yeryüzünde yaşayan insanlar, kötülük yaptıklarında burada cezalandırılacaktır. Türklerin eskatolojisinde kötülüğün artması, babaya duyulan saygının kalkması, dünya düzeninin bozulması gibi nedenler kıyamet alametleridir. Dünyanın sonu içinse kötülüğün tanrısı Erlik ve iyiliğin tanrısı Ülgen'in bu bozulmuş düzendeki savaşı anlatılmaktadır. Bu savaşın sonunda Ülgen kazanacak ve iyilik, dünyaya hâkim olacaktır.

Kitabın Dördüncü Bölümünde (s.161-204) Hristiyan eskatolojik mitleri yer almaktadır. Diğer mitsel anlatılar gibi burada da dünyayı kötülük kapladığı zaman Tanrı cezalandırma işlemini uygulayacaktır. Hristiyanlığın eskatolojik mit anlatısında, bu cezalandırma esnasında insanlık yok olacaktır. Mesih'in gelişiyle birlikte ölümlü insanların hükümdarlığı sona ereceği için bundan sonra artık tanrısal krallık geçerli olacaktır. (s.175) Bu arada, Hristiyan eskatolojik mitlerinde Mesih'in iki kere geleceğine inanılmaktadır. İkinci gelişinde kutsal mekân olan Kudüs'te iyilerle birlikte bin yıl yaşayacağı inanc1 da hâkimdir. Kudüs, Mesih'in doğup yaşadığı yer olması nedeniyle önem taşımaktadır.

Kitabın Beşinci Bölümünde (s.205-259) İslam'ın eskatolojik mitlerinden bahsedilmektedir. İslamiyet'te Allah'ın varlığı ve onun gönderdiği kutsal kitap olan Kur'an-ı Kerim büyük önem arz etmektedir. Pek çok dinî kitap gibi Kur'an-ı Kerim'de de eskatolojik anlatılara ve tasvirlere yer verilmiştir. Kur'an-ı Kerim'de anlatılanlara göre kıyamet günü; ayın kararacağı, güneşin ve ayın bir araya geleceği, inkârcı insanların kaçacak yer arayacağı fakat sığınacak yer bulamayacağı bir gün olacaktır. Ayrıca o gün insanlar sağdakiler, soldakiler ve önde bulunanlar şeklinde üç gruba ayrılacaktır. (s.215) Ayın yarılması hadisesi, bir kiyamet alameti olarak bilinmektedir. Kamer suresi birinci ayette zikredilen "Kıyamet yaklaştı ve ay yarıldı." mealindeki ifadenin ele alındığ 1 hadis rivayetlerine göre, ayın yarılması Hz. Peygamber'in gösterdiği mucizelerden biri olarak kıyamet alameti sayılmıştır. (s.224) Güneşin batıdan doğması da büyük bir kıyamet alameti olarak zikredilmektedir. (s.226) $\mathrm{Bu}$ ve benzeri bazı hadiseler 
gerçekleştiğinde kıyamet yaklaşıyor demektir. O gün içinde yapılan hiçbir şeyin faydasının olmayacağı, insanların o büyük sonla karşı karşıya gelecekleri şüphesizdir. Zamanın kısalması da kıyamet alameti olarak İslam kültüründeki yerini almıştır. (s.227) Öyle bir dönem gelecek ki insanlar geçen zamanın farkına varamaz olacaklar. Günler saatler gibi, saatler dakikalar gibi, dakikalar saniyeler gibi hızla geçecek; bu hızlı geçen süreç insanlığı kıyamete götürecektir. Kıyamet günü "Duhan" adlı bir dumanın zuhur edeceği söylenmektedir. Bu duman, bütün yeryüzünü kaplayacak ve göz gözü görmez olacaktır. Bu dumanın ardından İsrafil adlı melek Sûr'a üfleyecek, böylece o büyük sonun geldiğini ve kıyametin kopacağını haber verecektir. İsrafil ilk üfleyişinde kıyameti haber verecek, ikinci üfleyişinde ise ölüler dirilecektir. Ardından bütün insanlık, Allah'ın huzurunda toplanacaktır.

Zerdüştlükte "Saoşyant", Yahudilik ve Hristiyanlıkta ise "Mesih" olarak geçen ve kıyamet günü iyilik için gelecek olan karakterlerin amaçları ortaktır. Yeryüzüne inme sebepleri insanları kötülükten uzaklaştırmak, ihya etmek ve onlara doğru yolu göstermektir. Hepsi de iyi karakterlerdir. Lakin eskatolojik anlatılarda kötü karakterlere de rastlamak mümkündür. İran eskatolojisinde Dahhak, İbrani, Hristiyan, İslamiyet eskatolojilerinde Deccal, Ye'cuc-Me'cuc (Gog-Magog) gibi kötü karakterlere rastlamaktayız. Üç semavi dinin ortak eskatolojik sonu olarak sayılabilecek husus ise, bu karakterlerin yeryüzüne inme zamanları ve görevleridir. Saoşyant ve Mesih karakterleri kıyamet gününde gelecek ve iyiliği temsil edecektir. Dahhak, Deccal, Ye'cuc-Me'cuc (Gog-Magog) gibi karakterler ise kıyamet gününde kötülüğü temsil edeceklerdir. Üç büyük dinde de iyilik ve kötülüğün savaşında mutlaka iyilik kazanacaktır.

Kudüs üç büyük din için de kutsallık taşımaktadır. Yahudiler için Kudüs, Süleyman tapınağının bulunması açısından önem arz etmektedir. Hristiyanlıkta Kudüs'ün hac mekânı olması ve Mesih İsa'nın ikinci gelişinde Kudüs'e geleceğine inanılması burayı önemli bir yer kılmaktadır. İslamiyet içinse Kudüs, Hz. Peygamber'in miraç hadisesinin geçtiği yer olması hasebiyle önemlidir.

Kısacası insanların ve dünyanın bir sonu olduğu gerçeği, yadsınamaz bir durumdur. Bunun doğal bir sonucu olarak olaylar değişse de her kavmin mitik bir son inancı oluşmuştur. Klyamet Mitolojileri (Kurtla Klyamete Kalmak) adlı kitap; Türk, İran, İbrani ve Hristiyan kıyamet metinleri hakkında bilgi edinmek isteyenlerin başucu kitabı olacak derecede değerli bir çalışmadır. Bu eser sayesinde okurlar, bahsi geçen mitik kıyamet anlatılarını karşılaştırmalı olarak okuma firsatını bulacaktır. 